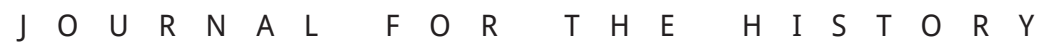

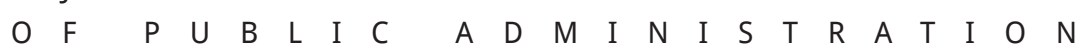

$\begin{array}{llllllllllll} & O & L & \mathrm{U} & \mathrm{M} & \mathrm{E} & 1 & 2 & 0 & 1 & 6\end{array}$

P A G E $138-154$

\title{
The Dutch Decentralized Unitary State and Its Effects on Civil Service Systems in the Period of the Night Watch, Welfare and Enabling States 1814-2016
}

\author{
FRITS VAN DER MEER, GERRIT DIJKSTRA, TOON KERKHOFF ${ }^{1}$
}

\section{Introduction}

From a geographical point of view, the Netherlands belongs to the smaller European states. Though small in size, it contains a considerable degree of cultural, historical, political and religious variation. Over the years, this variety has been an essential attribute of Dutch society and has to a large extent determined its political-administrative institutional design. Finding an acceptable equilibrium between unity and decentralization has influenced political administrative history from the Burgundian times till the present day. With the founding of the Kingdom of the Netherlands in the aftermath of the Congress of Vienna, a decentralized unitary state structure was introduced with the Constitution of 1815. This structure encompassed a considerable degree of autonomy and self-government for the various government levels within the framework of the unitary state. The importance attached to self-government is related to the view that decentralized government should be a vehicle for societal self-expression at all levels of the state. For our purposes it is important to note that autonomy and self-government also pertained to personnel management decisions and regulations regarding civil servants. ${ }^{2}$
Over time the nature, content and power relations within the decentralized unitary state did evolve, though the basic structure remained the same, as will be explained in section 2. Those changes also applied to the interconnection to society. In the period 1814-2016, the Dutch state went from being a Night Watch State, to a Welfare and Enabling State. Government initially had very little involvement in "public service delivery«. It dealt only with the most basic provisions such as safety, public order and finances. From the final quarter of the nineteenth century and especially after the Second World War, this changed, as government assumed a much more active role. The most recent decades have seen the emergence of an Enabling State where government is once again taking a step back. It creates necessary parameters but also tries to let `civil society` manage itself.

The central idea behind bureaucratic reform has been that changes within government and society have to be accompanied by parallel changes in civil service systems. The changing nature of the decentralized unitary state and the consequence for civil service systems can be analyzed by looking at the transition of dominant state models. In each of these models we can find an 
answer to what is expected of (senior) civil servants in terms of expertise, experience, attitude etc. - in short, the content of merit. How to shape and organize personnel tasks have thus been core issues in Dutch public administration and administrative thought. This involves a modification of personnel management policies and practices but also of requirements that are considered necessary for civil servants to operate in an appropriate way in these new conditions. 3 It thus also relates to the changing content of merit principles applied within Dutch civil service systems. In this contribution we will put emphasis on senior civil servants although in Dutch civil service regulations, such a category has not been well defined before the 1990s.

Our central question thus is: to what extent were the nature and content of merit principles for Dutch civil service systems influenced by the (changing) decentralized unitary state, during the periods of the Night Watch, Welfare and Enabling State between 1814 and 2016?

Before dealing with this question in the following sections, it is good to briefly elaborate on the use of history for the study of public administration and the need for historical comparison when evaluating current questions. The use of history for the study of public administration has been widely discussed in recent decades. ${ }^{4}$ The study of public administration benefits from historical research because the latter has "at its core the insight that a phenomenon can only be studied holistically, precisely because of its contingent qualities in time and space «. ${ }^{5}$ Similarly, an historical approach is thought to be useful because it helps to show limits and possibilities of generalization in understanding and explaining long-term social processes. This means that »for a proper understanding of contemporary structures and relations in public administration a geographical and historical setting is of great importance [...]. Without knowledge of the geographical and historical context, we are not able to assess neither the uniqueness nor the comparability of societal phenomena $« .{ }^{6}$ Administrative history thus provides a long-term perspective that can reveal "the fundamental dynamics of state building «. ${ }^{7}$ Naturally this applies to the study of civil service systems as well. A long-term perspective enables us to see more fundamental developments and offers possibilities to assess motives, intentions and context of changes in civil service systems over time until the present day.
A temporal perspective is not only a merit and interesting on its own but is also of prime importance for understanding the nature of current issues confronting government bureaucracy and human resources management policies and practices. Past events and experiences, for better or worse, are important for comprehending contemporary problems in the public domain and for finding appropriate solutions to deal with these challenges. $^{8}$

This article is structured as follows. In the next section we will look into the theoretical concepts of the decentralized unitary state, civil service systems, merit and the transition of state models. Next we present our empirical findings using a chronological order based on crucial periods and junctures in the development of the Dutch state from 1815 onwards. Finally we provide an answer in our conclusion.

\section{The Dutch decentralized unitary state and the effects on civil service systems in the era of the Night Watch, Welfare and Enabling State: concepts and models}

The decentralized unitary state, changing models of state, and civil service systems are key concepts in our analysis. These concepts are in need of explanation given their sometimes ambiguous meaning. But first we should discuss the importance of an historical administrative discussion of Dutch civil service system change in relation to the decentralized unitary state. With some reservation and care we will envisage a Dutch administrative tradition and model. The Thorbeckian model of the decentralized unitary state, the importance of the involvement of society in the public domain and the formulation these have taken in the periods of the Night Watch, Welfare and Enabling State can be seen as part of that Dutch administrative tradition and even - written perhaps with some more caution - administrative model.

To begin with the decentralized unitary state, after the overthrow - or more accurately, the collapse - of the Dutch Republic (1795) a unitary state was formed as result of the constitution of 1798 . How to strike an accept- 
able balance between centralism and decentralism was a lasting point of endless debates up until the annexation to Napoleonic France in 1810 . With the creation of the Kingdom of the Netherlands in 1815, a more stable decentralized unitary state structure came into existence encompassing the central state, provinces, municipalities and some functional governments. Although formally decentralized and constitutionally bound, in practice the first monarch after independence, King William I, concentrated power in his own hands. His personal rule also had significant effects on the functioning of the civil service systems. This monarchic rule ended with the liberal Constitution of 1848 introduced by Johan Rudolf Thorbecke, whose name still is associated with the constitutional design of the modern Dutch state. With him the modern-day decentralized unitary state began in earnest. The decentralized unitary state was meant to remedy both the institutional weakness of the Dutch Republic and some of the oppressive aspects of a strong central state which became manifest during the years of the French annexation and to a lesser degree the autocratic rule of King William I. ${ }^{9}$ The decentralized unitary state, according to the intentions of Thorbecke, was to combine the positive elements of the Dutch Republic (mostly self-governing cities) with the powerful administrative capabilities of a vigorous central state that was developed during the French era.

The concept of the Dutch decentralized unitary state states that within the public domain the unitary state is composed of primarily general-purpose governments such as the central government, provincial governments, and municipalities, and (to a lesser extent) of functional bodies such as water boards. The preference for general-purpose governments stems from the emphasis on integral public service delivery and citizen involvement. The sovereignty of the state is invested in each government according to the responsibilities assigned in the Constitution and institutional laws. For instance municipalities are not considered to be solely derived from central government but seen as a unique embodiment of the state and, according to Thorbecke's organic state theory, contributing to the growth of society and state. This idea is central to the Thorbeckian system as it still (at least formally) exists. In this Thorbeckian conception, the decentralized state is seen as instrument and vessel for citizens' involvement and so- cietal development in the public domain. Public domain can be seen as a vague term and is often barely defined. In addition to government (the public-public domain), a private-public domain can be distinguished. ${ }^{10}$ The private-public domain includes social self-management by citizens, social groups, civil society as well as the involvement of companies that enables the implementation of public tasks. As argued, this private-public domain has been considered essential since the early 19th century till the present day. It took shape in voluntary citizens' action under the Night Watch state. During the greater part of the Welfare State era it took the form of the pillarized society. Pillarization involved the vertical self-organization and service delivery of parts of society on the basis of a shared religious or social democratic worldview. >Vertical refers to pillars which included all classes from the lower to higher segments of society. After the 1970s, with the (partial) collapse of the pillarized society, a more individualized form of a participatory society manifested itself. This coincided with the rise of the Enabling State.

Over time, the decentralized unitary state system developed and provided the institutional context for the expansion and modernization of government and changing government relationships with society. This has had profound effects on civil service systems, as we will show below. Toonen (1987) ${ }^{11}$ argues that the Thorbeckian design proved to be flexible enough to adapt to societal needs of the day in the periods of the Night Watch, Welfare and Enabling States. In these different models of state, the changing character, tasks and relations within the Dutch decentralized unitary state and its relation to society become apparent. This in its turn defined the development of civil service systems. In the figure below ${ }^{12}$ a classification of the defining dimensions of these state models is presented using dimensions which consist of the depth of state depth of state intervention: societal penetration; the scope of government intervention regarding the dominant task areas undertaken by the public administration and the State community; the preferred intervention approach in terms of timing (reactive versus proactive); routing of intervention (indirect versus direct); delivery style (regulatory versus producing); use of public power (limited vs. strong); (state) strength (limited to high); the nature (formal vs. informal) and type of intervention 
instruments (legislation, financial and communication instruments); preference in intra- and extra-state coordination mechanisms (hierarchical, market, communi- tarian) and finally the role and attitude of civil servants within government and towards society. These will return in our discussion in the next sections.

\begin{tabular}{llll} 
& Night Watch State & Welfare State & Enabling State \\
\hline $\begin{array}{l}\text { Depth of state intervention: } \\
\text { societal penetration }\end{array}$ & Limited/ medium & Extensive & Extensive \\
\hline $\begin{array}{l}\text { Scope of state intervention: } \\
\text { dominant tasks }\end{array}$ & Public Law Safety & Full range & Public Law Safety + \\
& & & Enabling tasks
\end{tabular}

\section{INTERVENTION APPROACH}

\begin{tabular}{llll}
\hline Timing & Reactive & Proactive & Proactive \\
\hline Routing & Direct & Indirect + Direct & Indirect + Direct \\
\hline Delivery Style (dominant) & Regulatory & Provision through & Regulatory and \\
intermediary bodies & Societal coproduction & Strong \\
$\begin{array}{llll}\text { Use of public power } \\
\text { performing core tasks }\end{array}$ & Strong & Limited & High
\end{tabular}

\section{INTERVENTION INSTRUMENTS}

\begin{tabular}{|c|c|c|c|}
\hline (In) Formal & Formal & Formal + informal & Formal + Informal \\
\hline Type & Legislation & $\begin{array}{l}\text { Legislation + Financial + } \\
\text { Communicative }\end{array}$ & Legislation + Financial \\
\hline $\begin{array}{l}\text { Primary coordination } \\
\text { mechanisms }\end{array}$ & $\begin{array}{l}\text { 1. Hierarchy } \\
\text { 2. Market }\end{array}$ & $\begin{array}{l}\text { Pillarized Communitarian } \\
\text { Hierarchy Market }\end{array}$ & $\begin{array}{l}\text { 1. Hierarchy } \\
\text { 2. coproduction with the } \\
\text { private public domain } \\
\text { 2. Market }\end{array}$ \\
\hline CSS & Classical bureaucrat & Professional official & $\begin{array}{l}\text { Public servant bound to } \\
\text { government and society }\end{array}$ \\
\hline
\end{tabular}

Figure 1: Dutch models of state: an analytical approach (amended from Van der Meer 2012)

To this point, the concepts of civil service and the civil service system have been used indiscriminately. Within English-language research in public administration, administrative science and administrative history by authors from various countries, the terms scivil servants and sthe civil service` are used quite freely. The English-language term >civil service can be confusing as, in the British context, the words >civil service often are reserved for those public officials working for central government. Confusion can arise in an international con- parable to the sfonction publique in France, 'Beamten in Germany or sambtelijk apparaat « in the Netherlands. In order to make comparative studies possible, the civil service concept has been de-anglicized and stretched to other (central) government bureaucracies. Nowadays in international civil service studies the term refers to public (permanent) officials working at all levels of government. Thus it pertains to the (permanent) government workforce excluding political officials. The concept of the civil service system has been a further addition for enhancing comparisons by focusing on the historical insti- 
tutional dimension of civil services. A civil service system (CSS) is defined by Bekke, Perry and Toonen as institutions (i.e. rule complexes) that mobilize human resources in the service of the state in a given territory ${ }^{13}$. Crucial for our purposes is that civil service systems refer to the mobilization of human resources and thus pertain to such elements as the recruitment, promotion, deployment and career development of public officials. Deployment within a civil service system involves the position of civil servants within a public organization according to the needs and requirements of that particular government. The concept of merit is crucial to this.

In administrative sciences and administrative history, the concept of merit (systems) is often used in and central to discussions on the modernization and bureaucratization of civil service systems. The answer to the question of what is meant by merit (and the subsequent merit system) might look easy at first glance, but in reality it is fraught with difficulties. Merit is a complex, ambiguous and changing notion. Often, to name but some examples of merit criteria that are considered appropriate to a particular job or career, knowledge, capabilities, experience, skills, and attitude are mentioned. These are relevant to recruitment and promotion and other personnel decisions in employment systems. In short, merit criteria relate to the fit between an applicant for a position or career and the organizational needs. In the public sector, these merit criteria have become equated with the requirements of government bureaucracies as formulated by Max Weber. They still form the tenets of what is perceived as proper personnel policies. In order to guarantee these merit principles of the best and most fitting, employment decisions have been governed by uniform and impersonal policies and procedures. From this definition it becomes clear that what is fitting and what is best can differ substantially. Here we arrive at the complexities mentioned earlier. The content of merit can vary according to the requirements of (government) organizations in view of their specific tasks, intervention approach and instruments (see figure 1). Even more significantly for our purpose, what is considered merit can differ according to place and over time - specifically, what was viewed as merit could differ from government to government within the decentralized unitary state. We examine this issue in detail in the next sections. As described above, organizational and social requirements have changed over time, as becomes manifest in the change from a Night Watch to a Welfare State and more recently an Enabling State. This influences what is expected of the role and position of civil servants at the different levels of government in the decentralized unitary state. At the same time it has an effect on what is required of civil servants in terms of knowledge, capabilities, attitude, skills and experience.

\section{Civil service system employment in the changing decentralized unitary state: recruitment, selection, remuneration and deployment}

In this section we will first look at the changing civil service employment over time and examine the division of powers and responsibilities regarding civil service employment within the decentralized unitary state. Also, the changing nature of that employment over time with respect to methods of recruitment, ways of remuneration, the perceived necessary qualifications and the deployment deficits through a lack of mobility will be addressed. We look into changes in the civil service system during the transition from the Night Watch to the Welfare State and in particular the Enabling State. Finally we will examine the effects of these substantive changes on discussion about the preferred legal position of these civil servants.

\subsection{The consequences of the changing decentralized unitary state for civil service systems up to and during the era of the Night Watch State.}

The principle of decentralization implied that from the outset hiring staff and formulating the entry and promotion requirements were considered the primary responsibility of each level of government. Municipal, provincial and central government were in charge of their own personnel policies and labor conditions. This decentralized setup explains why there has never been any truly centralized recruitment, promotion or remuneration system. Until fairly recently, the key tenet of decentralization also applied within central govern- 
ment itself. In departments or ministries, emphasis was put on individual ministerial responsibility for internal departmental policies and management, rather than this being a shared cabinet responsibility. As such, managerial departmental autonomy led to internal fault lines within central government, called compartmentalization. This meant that each department had a fairly high level of autonomy, including personnel policy and the institutionalization of principles of merit. A general lack of single-party dominance of the political system, even at the local level, meant that a single-party hold on the civil service seldom occurred. ${ }^{14}$

Thus, departmental and local compartmentalization has been a continuing feature in central and local government until quite recently, with respect to personnel management issues among others. We will return to this issue, as after the Second World War this compartmentalization was considered to have a profound negative effect on government performance and the civil service.

A particularity of Dutch civil service systems in the decentralized unitary state was the emphasis on a job system of recruitment and promotion. To a lesser extent career systems can also be found, although they are exceptions to the rule. ${ }^{15}$ Nevertheless their importance should not be underestimated. These exceptions include corps-like structures for the military, judiciary, police, diplomatic service and, till recently and to a certain extent, the Inland Revenue and the Department of Public Works. In addition, the colonial service in the former Dutch Indies (the Royal Dutch Colonial Army) was also based on this corps structure. With the exception of the latter, these career systems found their origin or their inspiration in the French era. ${ }^{16}$

From 1815 to the early 20th century, recruitment to civil service positions had a very closed nature and was confined to those well acquainted with administrative life. Family, compatible political and religious circles, and friends and acquaintances were the most important sources for recruitment to (senior) bureaucratic positions ${ }^{17}$. The elitist nature especially of the higher levels of central government civil service was furthermore strengthened by comparatively fairly low earnings and rather poor labor conditions in the greater part of the $19^{\text {th }}$ century.$^{18}$ Levels of earnings remained the same between 1828 and $1864 .{ }^{19}$ The main argument for keeping salaries pensated by the honor of holding public office - hence the use in Dutch of the Latin word 'honorarium «. Likewise, these poor labor conditions resulted in an aristocratization of the senior civil service in the early nineteenth century. ${ }^{20}$ With the passing of time these low wages led to serious problems. Given the gradual but on-going processes of formalization and bureaucratization of labor conditions during the 19th century, civil servants could not supplement their income through other ways than by private means. Especially in the case of lower and middle-ranking civil servants, this brought about a form of 'dignified' poverty. ${ }^{21}$ Family and political patronage played an important but diminishing role in recruitment during the 19th century. Nevertheless, criticism of senior civil servants having a low level of quality was virtually absent given the high level of pre-entry education.

Before the fundamental overhaul of the party-political divisions within governments after the introduction of universal male suffrage in 1917 and of active voting for women in 1919, senior civil servants were part of the dominant liberal elite. Likewise they were of a Dutch (non-orthodox) reformed background. This can be explained by the fact that most academic civil servants were recruited from the then-premier Dutch university in Leiden, which trained the national elite that had predominantly this political and religious disposition. Candidates from underprivileged religious groups such as Catholics and orthodox Protestants were only marginally recruited to senior positions due to their limited access to the university system, closed elite recruitment and religious discrimination.

When pointing to political aspects of recruitment and nomination procedures of civil servants, we have to keep in mind that organized political parties in the Netherlands only slowly acquired a hold on the political system. Political parties first came into existence during the last quarter of the 19th century. This process started with the founding of Protestant (ARP: 1879 and CHU: 1908) and later Roman Catholic (RKSP: 1926) confessional parties as part of the religious emancipation process of underprivileged religious groups. The social democratic party (SDAP: 1894) came into existence as a consequence of the so-called social question that was caused by the negative social side-effects of the industrialization of the Netherlands. An exception to the formally politically neutral method of recruitment is to be found in 
the appointments Thorbecke made to crucial provincial positions after 1848. As stated, Thorbecke was the driving force behind the new constitutional order of 1848. He appointed, for instance, new King's Commissioners in the provinces on the basis of shared political ideas. ${ }^{22}$ His principal motive was to realize a fundamental policy and/or system change by diminishing the grip of the old administrative vanguard through appointing loyal new officials. Nevertheless, recruitment on the basis of pure political allegiance rarely occurred during the 19 th and early 20th century. Political recruitment to senior civil service positions only became visible after the 1970s. Patronage on the basis of family, religious or political ties slowly but surely diminished after the 1880 s, merit became the dominant principle as enshrined in the on-going bureaucratization process of government and its civil service systems.

\subsection{The consequences of the changing decentralized unitary state for civil service systems in the era of the Welfare State 1880-1980s}

It is important for understanding the changes in government personnel policies and management after 1880 that with the growth and diversification of government tasks a need for a more professional and formalized bureaucracy did arise. The transition from the Night Watch to the Welfare State (as described in figure 1) involved the emergence of an extensive and complex range of tasks such as education, housing, health care, infrastructure, social affairs, welfare provisions and public enterprises. These tasks arose in addition to the law and order and safety tasks of the Night Watch State. In particular in the areas of social and health care, education and social housing, public service provision was shared with the societal pillars mentioned in our introduction. This implied the existence of, for instance, Catholic and Protestant schools, hospitals, and housing corporations next to (mainly) government institutions. For these institutions governments had an enabling function, though the actual term was not used. After the First World War they were increasingly financed from government budgets. The explanation for this can be found in the dominance of Catholic and Protestant parties in parliament from 1918 till the 1970s.
Given the complexity and nature of the new tasks, the setting of ambitious targets, the utilization of new kinds of work expertise stemming from a wide range of relevant disciplines, more direct and penetrating intervention methods and the need for a more proactive attitude of civil servants, all governments became more dependent on substantive civil service expertise in various task areas. ${ }^{23}$ An adequate supply of a trained and equipped workforce was needed in order to fill the increasing number of civil service vacancies. Next to the growing demand for technical experts in the areas mentioned above, the management of political administrative processes in terms of public policy and organization also generated a demand for generalist and professional civil servants.

After World War II the need for an able and professional civil service received an additional powerful boost by having to confront the immediate necessities of the post-war reconstruction, given the large-scale destruction which had occurred during the German occupation. This need was strengthened by the rapid social and economic development of the Dutch economy and society from the late 1950s and 1960s. The war had profound effects on the composition of the ruling political and administrative elites of power. While the changes to Dutch society and government were not as comprehensive and far-reaching as some might have wanted, significant reforms were introduced. Not only did the range of government tasks expand, while the tasks were intensified, but also the more proactive and interventionist government approach emerged in earnest as (central) government took the lead in a planned and systematic approach to confronting a wide range of social and economic issues. Because of the experience in World War II with (military) planning and strategy and still remembering the ineffective social and economic policies of the successive governments during the period between 1918 and 1940, a demand for a new civil service appeared: a civil service able to operate in these new demanding conditions. The War and its aftermath thus gave rise to, or at least stimulated the development of, a professional bureaucracy with an increased emphasis on technical experts rather than on the old classical administrative functions. ${ }^{24}$ In the emerging Dutch political science and public administration societies (consisting of practioners and academics) and the rel- 
evant academic periodicals, the urgency of these civil service reforms was also maintained.

The need for a more professional civil service led to a bureaucratization and professionalization of personnel management from the 1950s. At the central level of government, structural reform was introduced with the short-lived Central Personnel Bureau, the RPD (psychological tests), the RGD (medical services) and the ROI (central government training institute). These organizations were part of the Home Office. This development was mirrored in the larger municipalities. In essence, recruitment (policies) and human resources management practices in central government remained the domain of each department. The same is true for the larger municipal units and enterprises. The policy initiatives and programs mentioned above were rather technocratic (and rationalized), which befitted the dominant mood of the time. Not only was this attitude to be found within government itself, but it was also prevailing in the (growing) public administration professional and academic community. This rationalized and planned approach was short-lived, as it could not withstand resistance by other departments. The compartmentalized structure of central (but also of local) government, as described in section 2, proved to be detrimental to this centralized approach.

With the growth in tasks and personnel, the intensification of societal intervention and organizational proliferation of government in the post-World War II period, the negative effects of this organizational compartmentalization on public service delivery and civil service performance increased. With the diminishing importance of pillarized public service delivery after the 1970s - due in part to rapid secularization of Dutch society - there was an increase in responsibilities of and pressure on government organization in terms of growth of staff and finances. ${ }^{25}$ Negative effects were reinforced by the prevailing job system that had a negative effect on the inflexible deployment of civil servants, manifesting itself in deficient (inter)departmental and intergovernmental mobility. People did change jobs over the years but for the most part within their own ministerial or local government unit and on their own accord. Job-switching between the public and private sector was very limited. In addition, the institutional- frame was exceedingly difficult. Given the allocation of training budgets to decentralized units, training was primarily targeted at the needs of the particular function currently performed. The perspective of actual long-term public sector employment and training was hardly taken into consideration, as the training budget came from the particular unit where the official was employed.

Since the 1970s, external advisory committees ${ }^{26}$ were installed to come up with ideas to combat coordination deficits that occurred because of compartmentalization. In the reports of the external advisory committee Structure of Central Government Organization (Commissie Hoofdstructuur Rijksdienst), the need for a senior civil service was argued in order to diminish departmental compartmentalization and the negative side effects of the job system. Only much later, however, would such a senior public service be created with the Senior Public Service (Algemene Bestuursdienst or ABD) in 1995. The target group were senior and top civil servants with a management responsibility. The basic idea behind the ABD was that it could further (interdepartmental) mobility. Previous policies directed at increasing senior service mobility had proved to be largely ineffectual. Officials were expected to change positions and departments regularly. A directorate-general (bureau ABD) had been created at the Ministry of the Interior under the dual supervision of the minister of that department and the prime minister. Its function was to operate as a personnel office to the ABD. These recruitment tasks were accompanied by management development activities. ${ }^{27}$ Within the ABD a separate top management group (TMG) was established. This group consisted of permanent secretaries, inspectors-general and directors-general. These top civil servants are appointed for a particular position in a department for a maximum of seven years on recommendation of the Minister of the Interior and the Cabinet after undergoing an ABD selection procedure. They are currently employed by the Minister of the Interior and posted at a given ministry. This posting is done in consultation with the minister of the given department. ${ }^{28}$ In addition, new talent is being recruited for future ABD positions who will receive training and coaching in a so-called candidate programme. ${ }^{29}$ In addition to the $\mathrm{ABD}$ and TMG initiatives, there are management trainee programs (rijkstrainees) for aspiring 
higher civil servants recruited from university. Thus, in the last two decades the dominant job system has been amended by introducing career elements. The main driving forces have been the desire to increase employability and promote mobility schemes in order to enhance interdepartmental integration. What has been said above reflects the situation in central government, but local government and especially the larger municipalities are also moving in this direction.

Above we have looked into reform to combat compartmentalization and thereby increase centralization in the civil service system. Centralization also occurred in the particular and important form of collective wage and pension agreements for civil servants. After initial centralization immediately after World War II, there was a clear move towards decentralization. Prior to 1987 there existed a centralized negotiations system in the Netherlands. Though the Civil Service Act of those days specified that the different governments were in charge of their own labor relations, central government could take the lead by using the provisions in the law and force other governments to follow. This befitted the planned and guided wage policy of the time that existed until $1959^{30}$ and gave a predominant role to central government, as wage negotiations were led by the Minister of the Interior. As this centralized approach was considered increasingly unsatisfactory, the four labor unions for government personnel, the Minister of the Interior, the Association of Netherlands Municipalities (VNG), the Interprovinciaal Overleg (Interprovincial Consultation or IPO) and the Association of Regional Water Authorities (UVW) signed a protocol in 1994 to divide negotiations according to government sectors (>Protocol sectoralisatie van het overleg 1993 en 1994^). It was recommended to decentralize labor negotiations and create thirteen sectors for these negotiations. These sectors included: central government, defence, police, judiciary, municipalities, provinces, water boards, primary and secondary education, higher vocational education, universities, public sector research organizations, and university teaching hospitals. Employers' organizations negotiate with public-sector labor unions about working conditions and pay. Pensions and the nature of the public-sector negotiations system have been excluded. These are still discussed at the central level. Employers and labor unions have each been working together in their respective umbrella organizations. These organizations can meet each other in the Council of Public Sector Personnel Policy (Raad voor het Overheidspersoneelsbeleid).

\subsection{The consequences of the changing decentralized unitary state on civil service systems in the era of the Enabling State}

Since the middle of the 1980s, a slow but certain change from a Welfare State towards an Enabling State has become manifest in the Netherlands. The financial crises of the 1980s combined with what was considered to be an overloaded (primarily central) government that was not able to address the social and economic problems of the day. This led to a fundamental overhaul of the Welfare State. The shift mentioned earlier from a pillarized public service delivery to a governmental and a non- profit one in the 1970s also increased the pressure on the civil service (size) and stretched government finances. In order to solve these crises, cutbacks in the social policy domain, decentralization to local government, privatization and agentification of public tasks, downsizing civil services and increasing citizen participation in service delivery became the main policies. As a result the Welfare State was transformed and made way to an Enabling State. This Enabling State operates within the (administrative) traditional bounds of the decentralized unitary state and the prerequisite of citizen involvement in public service delivery. The Enabling State involves creating and supplying the necessary sgood conditions for (civil) society and the economy to take care of their own and the communal interest. Those societal interests are considered paramount. These conditions are often conveyed through the concepts of 'good governance and institutional capacity. ${ }^{31}$ The Enabling State shares some aspects of the 19th-century Night Watch State in regard to the importance of law-and-order safety tasks. At the same time, however, its task area, its way of operation, and its societal involvement are much broader. It also involves and stresses the defining tasks of government, much more than was the case with the Night Watch and Welfare States. ${ }^{32}$ This Enabling State can be proactive in having to create and supply necessary good conditions for the operations of the market economy and civil society. Those conditions refer to the maintenance of a re- 
liable and transparent legal and administrative system. Society, the business community and foreign investors should know and count on an effective and efficient operation of the legal system. This includes active care for an operational legal system, a neutral judiciary, open access to the courts, clear laws concerning property rights and contracts. In addition to these administrative legal aspects, emphasis is increasingly placed on independent regulatory agencies for guaranteeing the existence of full market conditions. The existence of a reliable financial system and development of a stable policy, the promoting and maintaining a modern system of physical infrastructure, and the development of human infrastructure by educating a well-trained workforce, are also included in the necessary conditions. Finally, government is expected to have a system responsibility for the state (institutions) in case of a breakdown of vital parts of society and the economy. In this respect it also has to function as a last resort and safety net for those in society that cannot take care of themselves. Here, a major difference with the Welfare State becomes apparent: government is a last but not a first resort. The first resort is society itself, which is enabled by government. As such, one can also speak of a transition from a Welfare State to a Welfare Society.

The role and position of the civil service towards the public (customers) and towards political officeholders (principals), as well as its preferred mode of functioning, have been and still are in a process of adapting to this new enabling role of the state (see figure 1). This implies that civil servants are recruited and trained for executing the classical law-and-order tasks and the Enabling State tasks mentioned above. ${ }^{33}$ The role of citizens and society is thus increasingly being emphasized with a supportive role for civil servants. Fewer and fewer civil servants are involved in the direct provision of welfare and production tasks, and more in facilitating or coordinating public service delivery. ${ }^{34}$ The exception is the implementation of law-and-order tasks, which are still predominantly the province of government and the civil service. Actual production tasks have been or are in the process of being privatized or decentralized to local governments, and then tendered out to profit or non-profit organizations or increasingly performed by citizens themselves. Civil servants in the Enabling State are mainly active in those areas where the unique and the areas where public authority is exercised, where a regulatory and supervising role is needed, a system responsibility is at hand and where it is operating as a societal facilitator. In the next section we will have look at what this implies for the legal status of civil servants.

Another implication is the idea that a snew civil servant is needed to be suitable in a snew < kind of public administration. ${ }^{35}$ Personnel cutbacks over the last decades and a limited new intake of staff have caused imbalance between the actual and the required qualities within the civil service system. To end on a negative note: retraining is needed but cutbacks on training budgets in the last decade make things quite difficult.

\subsection{The changing legal position of civil servants and the need for recruiting professional civil servants}

The expanding public service and the increasing demand for specialist and professional personnel had as a side effect a legislative push for a legally better protected service. ${ }^{36}$ During the 19th and early 20th centuries, the legal position of civil servants within the system of government was relatively weak given the absence of a legal framework. ${ }^{37}$ Thorbecke had already argued in 1848 that it was necessary to enshrine the position of civil servants in public law. Only much later, in 1929, was such an act enacted by parliament. Because of the need to attract skilled personnel, some social and protective measures were issued, starting with pensions and widow assistance schemes later in the $19^{\text {th }}$ century. ${ }^{38}$ As a result of efforts and pressure from within the civil service, assisted by legal experts like Krabbe with his influential dissertation (1883) ${ }^{39}$ and a state committee ${ }^{40}$, a Civil Service Act (CSA) was adopted in 1929. ${ }^{41}$ This act encompassed all levels of government. However, the CSA 1929 did not contain very detailed provisions. Instead, it provided a general framework and its operationalization depended on bylaws and regulations that were made by the various governments. For instance, in 1931 the General Regulation for Central Government Civil Servants (ARAR) was adopted. This process of regulating the formal position of civil servants also had effects on formalizing recruitment procedures and formalizing the inclusion of merit criteria within those procedures. ${ }^{42}$ It is, however, important to point to 
the fact that not everyone in the public service was an official subject to the CSA. The CSA left open an option that governments could employ staff on the basis of a contract of employment under civil law. This especially related to lower and temporary positions. In $194769 \%$ of public servants were employed on the basis of an employment contract. ${ }^{43}$ Today, this category does not exist, as virtually all public servants are employed under the CSA. In 1995, the applicable regulations concerning contract agents were withdrawn. ${ }^{44}$ By means of privatization, contracting out and agentification, these categories of positions have now virtually disappeared.

The legal position of civil servants has remained a point of contention since the 1950s. Changes in the role and functions of government combined with the better legal protection of private labor protection raised the question whether a public law status for civil servants was still necessary. This issue lingered for many years while some material points (such as labor negotiation and the right to strike) were harmonized. In the 2010s the debate has intensified and a member initiative has been sent to the Second Chamber to abolish the public law appointment of the larger part of the civil service..$^{45}$ These officials remain in the employ of government and keep a civil service status, but are given a contract of employment on a private-law basis. Specific public-law regulation regarding, for instance, integrity, but also a wage cap for top civil servants remains in force. The military, police, political office holders and judges keep their appointment under public law. This equalization of the public with the private-law position is called snormalization`. The arguments provided by its supporters included the increase of mobility between the private and public sectors. At the same time, it would be easier to dismiss officials. A third reason that is often mentioned is that at present two systems coexist, namely a private labor law and a public-law one. During the debate emanating from this proposal, the initiative and its supporting arguments were heavily criticized by the Council of State and public administration experts for lacking consistency and empirical evidence for supporting the arguments. ${ }^{46} \mathrm{An}$ important point is that with the change from a Welfare to an Enabling State, civil service employment has been confined to the classic law-andorder and societal facilitating tasks. Here the unique and the binding nature of the government are visible.

\section{Conclusion and final remarks}

The central question we addressed was to what extent the nature and content of merit principles for Dutch civil service systems were influenced by the changing decentralized unitary state, during the periods of the Night Watch, Welfare and Enabling State between 1814 and 2016.

We have argued that the Dutch case of the effects of the decentralized unitary state on civil service systems is interesting to study as it was meant as a compromise and solution to the failing particularistic and decentralized confederative structure of the Republic and the oppressive centralized arrangements during the annexation to France. The current formulation of the decentralized unitary state is the inheritance of the legislative work of the leading Dutch 19th-century statesman Johan Rudolph Thorbecke. The basic tenets were that the decentralized unitary state is made up primarily of general-purpose governments (central government, provincial governments and municipalities) and secondarily of functional bodies such as water boards. In each of these governments, the sovereignty of the state is embodied. The Thorbeckian model of the decentralized unitary state with its emphasis on the autonomy and self-government of its constituent components also stressed the central place and involvement of society in the public domain. That role of the citizens took shape as voluntary citizens' action during the Night Watch State. In the larger part of the Welfare State years, from the 1880s to the 1970s, it manifested itself in the pillarized society. After the 1970s and the partial collapse of pillarized society, there was a movement towards a more individualized form of a participatory and coproducing society coinciding with the emergence of the Enabling State. Together these features can be seen as crucial components of the Dutch administrative tradition and administrative model. That tradition has remained a lasting feature during the periods of the Night Watch, Welfare and Enabling State with its influence on the place, role and functioning of the civil service systems adapting to the needs of time.

In accordance with the decentralized unitary structure, personnel management and regulations were considered the prime responsibility of each government. For instance, with the exception of mentioning the existence of a town clerk and receiver, no provisions were inserted in the Municipal Law concerning local government civil 
services. The same is true with respect to other institutional laws. In addition, the Constitution stipulates that the position of civil servants should be regulated by law but the exact way is left open. The Civil Service Act 1929 only provides a general outline that was to be made concrete in local regulations. With the exception of the years of centralization immediately after World War II, wage agreements, labor negations and settlements have in general been very much decentralized since 1994, although mutual consultation between government employers did and does exist. As such rivalry between central and local levels of government regarding competencies and recruitment rarely has rarely occurred or been acted upon, except perhaps in the interlude mentioned above regarding wage negotiations.

We have argued that civil service requirements have changed due to changes in the public sector and society, as is visible in the consequences of the transition from a Night Watch to a Welfare State and more recently the Enabling State. That transition influences what is expected of the role and position of civil servants at the different levels of government in the decentralized unitary state. At the same time it had an effect on what is required of civil servants in terms of knowledge, capabilities, attitude, skills and experience. The early 19th century system of recruitment, promotion and deployment was at first primarily based on personal relationships. That already changed during the later Night Watch State era with the ongoing bureaucratization of administrative procedures. Though patronage still played an important role during this particular era, the effects on civil service quality were limited given the high level of pre-entry education. During this period senior civil servants predominantly had a legal background, working in such areas as law and order and general administration. While they were able to use the power of the state, the scope and depth of intervention in societal affairs was limited and reactive.

That changed with the rise of the Welfare State, starting towards the end of the 19th century and coming to full bloom after 1945. The expansion and diversification of public tasks, particularly at the municipal level, necessitated a more professional and formalized bureaucracy. This range of tasks comprised education, housing, health care, infrastructure, social affairs, welfare provisions and public enterprises. The management of polit- ical, public policy and organization processes increased the demand for well-trained generalist civil servants. Technical experts were needed in these areas next to expertise needed for law and order and general administration. The complex character of these extensive Welfare State tasks, the accompanying ambitious objectives, the application of new work methods derived from a wide range of relevant disciplines, the direct and penetrating intervention methods and the need for a more proactive attitude of civil servants necessitated a new civil servant. The necessity led to specialized training and education programs as well as the professionalization of personnel management.

Given this urgency, local government made the earliest steps in the process of adapting to the new civil service. During the early days of the Welfare State, the proliferation of government tasks originated at the municipal level, given the pressing social and economic needs of the day. Likewise, training for (specialist and generalist) civil service jobs started at the municipal level. As an example, the initiative for extensive public administration training and education started at the local level and gradually also came to central and provincial governments. Public administration, economics and social sciences eroded the monopoly of legal training within the Dutch civil services. Programs were developed at administrative academies and in the final quarter of the 20th century also at universities, a feature the Netherlands shared with the USA. Central government became involved in earnest after the Second World War when it took central stage in public service delivery.

From the early 1980s, the Welfare State gradually gave way to an Enabling State. Primary causes were the financial crisis of the 1980s, the overburdening especially of central government, and its problems with handling current social and economic problems. In addition, a more ideological dimension was at play relating to the processes of individualization, the popularity of political and economic neoliberalism and the ongoing depillarization of Dutch society. Cutbacks in social expenditure, decentralization to local government, privatization and agentification of public tasks, downsizing civil services and increasing citizen participation in service delivery were seen as the best way to tackle these issues. This led to an erosion of a state-led welfare system. The Enabling State emerged. We have defined an Enabling State as 
involved in generating and supplying the necessary good conditions for (civil) society and the economy to take care of its own and the communal interest. Those societal interests are considered paramount. These conditions are often conveyed through the concepts of good governance and institutional capacity. ${ }^{47}$ The Enabling State shares, to a certain extent, the core tasks of the Night Watch State: the importance of law, order and safety tasks. At the same time, as stated, its range of tasks, its way of operation and societal involvement is much more extensive and more proactive. This also includes the tasks of supplying the right conditions for societal development and self-governance as described above, much more than was the case of the Night Watch and Welfare States. ${ }^{48}$

The role and position of the civil service towards the public (customers), political officeholders (principals) and its preferred mode of functioning have been and are still being adapted to this new enabling role of the state. This implies that civil servants are recruited and trained for executing the classical law-and-order tasks and the Enabling State tasks mentioned above. The role of citizens and society is thus increasingly being emphasized with a supportive or facilitating role for civil servants. Fewer and fewer civil servants are involved in welfare and production tasks and more in facilitating or coordinating public service delivery. The exception is the implementation of law-and-order tasks that are still predominantly the domain of government and the civil service. Again a snew civil servant is needed to fit the new job requirements. Personnel cutbacks over the last decades and a limited new intake of staff have caused a mismatch between the actual and the required qualities within the civil service. A retraining is necessary but cutbacks in the training budget have made things quite difficult. Civil servants in the Enabling State are predominantly active in areas where the unique and binding nature of the government is visible. We pointed to a system responsibility in the exercise of public authority in areas where the regulatory and supervising role of government is essential and where the function of a societal facilitator is needed. That special nature has been and still is an argument to create and keep a special public law status for civil servants. 
B E K K E, Hans A. G. M. / P E R RY, James L. / TO O N E N, Theo A. J. (Eds.): Civil Service Systems in Comparative Perspective, Bloomington/ Indiana 1996. B ER G , Caspar F. van der / M E ER, Frits M. van der/ D IJ KS TRA, Gerrit S. A.: »Traditions, Bargains and the Emergence of the Protected Public Servant in Western Europe«, in: Fritz Sager, Patrick Overeem (Eds.), The European Public Servant. A Shared Administrative Identity?, London 2015 (a), p. 117-135. B R A A M , Aris van: Ambtenaren en bureaukratie in Nederland, Zeist 1957. CALDWELL, Lynton K.: "The relevance of administrative history", in: International Review of Administrative Sciences 21 (1955), p. 453-466. COM MISSIE VAN VEEN: Rapport van de Commissie Interdepartementale Taakverdeling en Coördinatie, 's-Gravenhage 1971. COMMISSIE HOOFDSTRUCTUUR RIJKSDIENST (VONHOFF): Elk kent de laan die derwaarts gaat, rapport 3, 's-Gravenhage 1980. - Voordat de lade klikt, 's-Gravenhage 1981. • Eindadvies, 's-Gravenhage 1981. D IJ K S TRA, Gerrit S. A. / MEER, Frits M. van der: "The civil service system of the Netherlands", in: Frits M. van der Meer (Ed.), Civil service systems in Western Europe, Cheltenham, Aldershot 2011, p. 157-191. • - / / B E R G, Caspar F. van den: "Is er nu wel of niet sprake van een terugtredende overheid?«, in: Jaap J. M. Uijlenbroek (Ed.), Staat van de ambtelijke Dienst, Den Haag 2015 (b), p. 23-37. D R E SSELH U Y S, Hendrik Coenraad: Verslag van de Staatscommissie ter voorbereiding van algemeene wettelijke regelen betreffende den rechtstoestand van ambtenaren (ingesteld bij Kon. Besluit van 21 mei 1917 No. 27), 's Gravenhage 1919. K R A B B E, Hugo: De burgerlijke staatsdienst, Dissertation, Leiden 1883. K R O E Z E, Ronald: Een kwestie van politieke moraliteit. Politieke corruptieschandalen en goed bestuur in Nederland. 1848-1940, Hilversum 2013. L Y N N , Laurence E.: Jr., Public management: old and new, New York 2006. M E E R, Frits M. van der / RAADSCHELDERS, Jos C. N.: "Between Restauration and Consolidation: The Napoleonic Model of Administration in the Netherlands 1795-1990«, in: Bernd Wunder (Ed.), The Napoleonic Model of Government, Brussels 1995, p. 199-221. - "The unification of the civil service pension system in the Netherlands 1798-1922 «, in: Bernd Wunder (Ed.), Pension systems for public servants in Western Europe 19th/20th century, Baden-Baden 2001, p. 113-127. • - / / / T O O N E N, Theo A. J.: "Modelos administrativos, tradiciones y reformas. ¿último recurso explicativo?«, in: Estado, Gobierno, Gestión Pública. Revista Chilena de Administración Pública 12 (2008), p. 85-103. • »Public Sector reform in Western Europe and the rise of the Enabling State: an approach to analysis«, in: Rohit Mathur (Ed.), Glimpses of Civil Service reform, Hyderabad 2009, p. 171-195. • - / RAA D S C HELDERS, Jos C. N. / KERKH O F F, Toon D. N.: »Van nachtwakersstaat naar waarborgstaat. Proliferatie en vervlechting van het Nederlandse openbaarbestuur in de lange twintigste eeuw (1880-2005)«, in: Pieter Wagenaar, Toon D. N. Kerkhoff, Mark R. Rutgers (Eds.): Duizend jaar openbaar bestuur in Nederland: Van patrimoniaal bestuur naar waarborgstaat, Bussum 2011, p. 221290. - (Ed.), Civil Service Systems in Western Europe, Cheltenham, Aldershot 2011. - Voorwaarden, waarborgen en ambtenaren. De gevolgen van de opkomst van de voorwaardenscheppende staat voor de publieke dienst, Leiden 2012. • - / B E R G, Caspar F. van den / D I J KSTRA, Gerrit S. A.: Het eigene van de overheid en haar personeel in een systeem van multi-level governance: naar een nieuwe ambtelijke status, Leiden 2012. • "Minder overheid, maar wie denkt er na over de lange termijn?«, in: Mejudice www.mejudice.nl/artikelen/detail/minderoverheid-maar-wie-denkt-er-na-over-de-lange-termijn (Date: November 18, 2014). •-/RA A D S C HE L DER S, Jos C. N. / T O O N E N, Theo A. J.: The Civil Service in the 21st Century, Completely Revised 2nd edition: Comparative Perspectives, Houndsmill 2015. • - / B E R G , Caspar F. van den: "Government and society in the active and the enabling state: A framework for analyzing transitions across time and place«, paper pre- sented at the IRSPM conference 2016 in Hong Kong 2016. P O E LJ E, Gerrit A. van: »De gemeente-ambtenaar«, in: H. Th. Klein, et al. (Ed.), Gedenkboek uitgegeven ter gelegenheid van het 40-jarig bestaan van den Nederlandschen Bond van Gemeente-Ambtenaaren, Alphen aan den Rijn 1933, p. 106-114. R A A D S C H E L D E R S, Jos C. N.: »Administrative History: Contents, Meaning and Usefulness", in: International Review of Administrative Sciences 60/1 (1994), p. 117-129. • - / R U TG E R S, Mark R.: »The Evolution of Civil Service Systems«, in: Hans A. G. M. Bekke, James L. Perry, Theo A. J. Toonen (Eds.), Civil Service Systems in Comparative Perspective, Bloomington 1996, p. 67-99. - Handbook of Administrative History, New Brunswick, etc. 1998. - et al., "Against A Study of the History of Public Administration: A Manifestou, in: Administrative Theory and Practice 22/4 (2000), p. 772-791. • "Is American public administration detached from historical context? On the nature of time and the need to understand it in government and its study", in: American review of public administration 40/3 (2010), p. 235-260. R A N D E R A A D, Nico, „Civil Servants in Nederland (1815-1915)«, in: Bijdragen en Mededelingen over de Geschiedenis van Nederland 2/109 (1994), p. 209-236. S T E K E L E N B U R G , Mikis, 200 jaar werken bij de overheid, 2 volumes, Den Haag 1999. T I L LY, Charles, »Why and how history matters", in: Robert E. Goodin, Charles Tilly (Eds.), The Oxford handbook of contextual political analysis, Oxford, etc. 2008, p. 417-437. T O O N E N, Theo A. J., Denken over binnenlands bestuur: theorieën van de gedecentraliseerde eenheidsstaat bestuurskundig beschouwd, 's Gravenhage 1987. V A U G H N , Stephen (Ed.), The vital past: writings on the uses of history, Athens 1985. IJ S S E L M U I DE N, Pieter G. van, Binnenlandse Zaken en het Ontstaan van de Moderne Overheidsbureaucratie in Nederland 1813-1950, Kampen 1988. 
1 Frits van der Meer, Gerrit Dijkstra and Toon Kerkhoff are working at and for the Institute of Public Administration Leiden University.

2 In accordance with practice in the field of comparative civil service systems, civil servants and public servants are considered to be synonymous.

3 Frits M. van der Meer, "Public Sector Reform in Western Europe and the Rise of the Enabling State: an Approach to Analysis", in: Rohit Raj Mathur (Ed.), Glimpses of Civil Service Reform, Hyderabad 2009, p. 171-195; Frits M. van der Meer, Voorwaarden, waarborgen en ambtenaren. De gevolgen van de opkomst van de voorwaardenscheppende staat voor de publieke dienst, Leiden 2012.

4 See, amongst many others, Lynton K. Caldwell, "The Relevance of Administrative History«, in: International Review of Administrative Sciences 21 (1955), p. 453-466; Jos C. N. Raadschelders, "Administrative History: Contents, Meaning and Usefulness«, in: International Review of Administrative Sciences 60 (1994), p. 117-129; Jos C. N. Raadschelders, et al., "Against A Study of the History of Public Administration: A Manifesto«, in: Administrative Theory and Practice 22 (2000), p. 772-791; Jos C. N. Raadschelders, »Is American Public Administration Detached From Historical Context? On the Nature of Time and the Need to Understand It in Government and Its Study", in: American Review of Public Administration 40 (2010), p. 235-260; Charles Tilly, "Why and How History Matters", in: Robert E. Goodin, Charles Tilly (Eds.), The Oxford Handbook of Contextual Political Analysis, Oxford, etc. 2006, p. 417-437; Stephen Vaughn (Ed.), The Vital Past. Writings on the Uses of History, Athens [GA] 1985.

5 Raadschelders, et al., "Against a Study«, p. 782.

6 Jos C. N. Raadschelders, Handbook of Administrative History, New Brunswick, etc. 1998, p. 9.

7 Laurence E. Lynn Jr., Public Management: Old and New, New York 2006, p. 22.

8 Frits M. van der Meer, Jos C. N. Raadschelders, Theo A. J. Toonen, "Modelos administrativos, tradiciones y reformas. ¿Último recurso explicativo?«, in: Estado, Gobierno, Gestión Pública. Revista Chilena de Administración Pública 12 (2008), p. 85-103.

9 Frits M. van der Meer, Jos C. N. Raadschelders, »Between Restauration and Consolidation: The Napoleonic Model of Administration in the Netherlands 1795-1990«, in: Bernd Wunder (Ed.), The Napoleonic Model of Government, Brussels 1995, p. 199-221, here p. 220.

10 Frits M.van der Meer, «Minder overheid, maar wie denkt er na over de lange termijn?«, in: Mejudice www.mejudice.nl/artikelen/detail/minder-overheid-maar-wie-denkt-er-na-over-de-lange-termijn (Date: November 18 2014).

11 Theo A.J. Toonen, Denken over binnenlands bestuur: theorieën van de gedecentraliseerde eenheidsstaat bestuurskundig beschouwd, 's Gravenhage 1987.

12 Van der Meer, Voorwaarden, waarborgen en ambtenaren; Frits van der Meer, Caspar F. van den Berg, "Government and society in the active and the enabling state: A framework for analyzing transitions across time and place«, paper presented at the IRSPM conference 2016 in Hong Kong 2016.

13 Hans A. G. M. Bekke, James L. Perry, Theo A. J. Toonen (Eds.), Civil Service Systems in Comparative Perspective, Bloomington/Indiana 1996, p. 2.

14 Gerrit S. A. Dijkstra, Frits M. van der Meer, "The civil service system of the Netherlands«, in: Frits M. van der Meer (Ed.), Civil service systems in Western Europe, Cheltenham, Aldershot 2011, p. 157-191.

15 Ibidem.

16 Van der Meer/Raadschelders, „Between Restauration and Consolidation«.
17 Aris van Braam, Ambtenaren en bureaukratie in Nederland, Zeist 1957; Nico Randeraad, "Civil Servants in Nederland (1815-1915)«, in: Bijdragen en Mededelingen over de Geschiedenis van Nederland 2/109 (1994), p. 209-236.

18 Pieter G. van IJsselmuiden, Binnenlandse Zaken en het Ontstaan van de Moderne Overheidsbureaucratie in Nederland 1813-1950, Kampen 1988.

19 Ibidem.

20 Ibidem.

21 Randeraad, "Civil Servants in Nederland«.

22 Ronald Kroeze, Een kwestie van politieke moraliteit. Politieke corruptieschandalen en goed bestuur in Nederland. 1848-1940, Hilversum 2013.

23 Gerrit A. van Poelje, »De gemeente-ambtenaar«, in: H. Th. Klein, et al. (Ed.), Gedenkboek uitgegeven ter gelegenheid van het 40-jarig bestaan van den Nederlandschen Bond van Gemeenteambtenaren, Alphen aan den Rijn 1933, p. 106-114.

24 Frits M. van der Meer, Jos C. N. Raadschelders, Toon D. N. Kerkhoff, „Van nachtwakersstaat naar waarborgstaat. Proliferatie en vervlechting van het Nederlandse openbaarbestuur in de lange twintigste eeuw (1880-2005)«, in: Pieter Wagenaar, Toon D. N. Kerkhoff, Mark R. Rutgers (Eds.), Duizend jaar openbaar bestuur in Nederland: Van patrimoniaal bestuur naar waarborgstaat, Bussum 2011, p. 221-290.

25 We point here to increased responsibilities but not actual service delivery. The greater part of the former health care and housing corporations on a religious basis continued as independent (managerially run) organizations on a non-religious basis. They merged with (municipal) facilities to become part of these new management-based organizations. The exception to this rule was primary, secondary and university education.

26 Commissie van Veen, Rapport van de Commissie Interdepartementale Taakverdeling en Coördinatie, 's-Gravenhage 1971; Commissie Hoofdstructuur Rijksdienst (Vonhoff), Voordat de lade klikt, 's-Gravenhage 1981; Commissie Hoofdstructuur Rijksdienst (Vonhoff), Eindadvies, 's-Gravenhage 1981; Commissie Hoofdstructuur Rijksdienst (Vonhoff), Elk kent de laan die derwaarts gaat, rapport 3, 's-Gravenhage 1980.

27 Dijkstra / Van der Meer, "The civil service system of the Netherlands«.

28 Ibidem.

29 Ibidem.

30 Mikis Stekelenburg, 200 jaar werken bij de overheid, 2 volumes, Den Haag 1999.

31 Van der Meer, »Public Sector reform in Western Europe«.

32 Van der Meer, Voorwaarden, waarborgen en ambtenaren; Van der Meer/Berg, "Government and society in the active and the enabling state«; Van der Meer, „Public Sector Reform in Western Europe and the Rise of the Enabling State«.

33 Frits van der Meer, Jos C. N. Raadschelders, Theo A. J. Toonen, The Civil Service in the 21st Century, Completely Revised 2nd edition: Comparative Perspectives, Houndsmill 2015.

34 Gerrit Dijkstra, Frits van der Meer, Caspar F. van den Berg, "Is er nu wel of niet sprake van een terugtredende overheid?«, in: Jaap J. M. Uijlenbroek (Ed.), Staat van de ambtelijke Dienst, Den Haag 2015 (b), p. 23-37.

35 Van der Meer, Voorwaarden, waarborgen en ambtenaren; Frits van der Meer, Caspar F. van den Berg, Gerrit S. A. Dijkstra, Het eigene van de overheid en haar personeel in een systeem van multilevel governance: naar een nieuwe ambtelijke status, Leiden 2012; Caspar F. van der Berg, Frits M. van der Meer, Gerrit S. A. Dijkstra, 
"Traditions, Bargains and the Emergence of the Protected Public Servant in Western Europe«, in: Fritz Sager, Patrick Overeem (Eds.), The European Public Servant. A Shared Administrative Identity?, London 2015 (a), p. 117-135.

36 Jos C. N. Raadschelders, Mark R. Rutgers, "The Evolution of Civil Service Systems«, in: Hans A. G. M. Bekke, James L. Perry, Theo A. J. Toonen (Eds.), Civil Service Systems in Comparative Perspective, Bloomington 1996, p. 67-99.

37 Van IJsselmuiden, Binnenlandse Zaken en het Ontstaan van de Moderne Overheidsbureaucratie in Nederland.

38 Frits M. van der Meer, Jos C. N. Raadschelders, "The unification of the civil service pension system in the Netherlands 1798-1922 «, in: Bernd Wunder (Ed.), Pension systems for public servants in Western Europe 19th/20th century, Baden-Baden 2001, p 113-127.

39 Hugo Krabbe, De burgerlijke staatsdienst, Dissertation, Leiden 1883.

40 Hendrik Coenraad Dresselhuys, Verslag van de Staatscommissie ter voorbereiding van algemeene wettelijke regelen betreffende den rechtstoestand van ambtenaren (ingesteld bij Kon. Besluit van 21 mei 1917 No. 27), 's Gravenhage 1919.

41 Dijkstra/Van der Meer, "The civil service system of the Netherlands".

42 Ibidem.

43 Stekelenburg, 200 jaar werken bij de overheid.

44 Ibidem.

45 Van der Berg/Van der Meer/Dijkstra, "Traditions, Bargains and the Emergence of the Protected Public Servant in Western Europe«.

46 Ibidem.

47 Van der Meer, „Public Sector reform in Western Europe«.

48 Van der Meer, Voorwaarden, waarborgen en ambtenaren; Van der Meer/van den Berg, "Government and society in the active and the enabling state«. 


\section{Abstract}

The central question on our article is: to what extent were the nature and content of merit principles for Dutch civil service systems influenced by the (changing) decentralized unitary state, during the periods of the Night Watch, Welfare and Enabling State between 1814 and 2016? In accordance with the decentralized unitary structure as originally devised by the 19th century Dutch statesman Johan Rudolf Thorbecke, personnel management and regulations were (and are) considered the prime responsibility of each (level of) government. Our article shows how neither in past nor present have there been hierarchical relationships in this area, with the exception of centralized wage settlements after the Second World War until the 1990s. In addition, we argue that civil service requirements have altered due to societal and public sector change. Those changes have become visible in a transition from a Night Watch to a Welfare State and more recently an Enabling State. This transition not only influenced what was expected of the role and position of civil servants at different levels of government in the decentralized unitary state. It also had an effect on what has over time been required of civil servants in terms of knowledge, capabilities, attitude, skills and experience. The article explains how the Thorbeckian decentralized unitary state provided a lasting but flexible format to accommodate these civil service system adjustments.

\section{About the Authors}

FRITS VAN DER MEER is CAOP professor in comparative public sector and civil service reform and working at the Leiden Institute of Public Administration. Besides his work on comparative civil service reform and comparative bureaucracy he has written extensively on administrative history of the Netherlands. He is also heading the Leiden centre for Public Sector Reform.

GERRI T DIJ KSTRA works as a senior lecturer at the Leiden Institute of Public Administration. His research is on the intersecting lines between law and public administration and more particular on the consequences of legal dimensions for Public Administration. He has published extensively amongst others on juridification of PA, the relationship between citizen and administration, the issue how to embed accountability, responsiveness and, responsibility within performance management and civil service systems.

T OON KERKHOFF works as a senior lecturer at the Leiden Institute of Public Administration. His research and teaching are characterized by a continuous and consistent historical approach to core questions in public administration and politics; most notably corruption, integrity, public values and civil service reform. 